\title{
Effect of Glucagon on Glucose Production during Insulin Deficiency in the Dog
}

\author{
alan D. Cherrington, William W. Lacy, and Jean-Louis Chiasson, \\ Departments of Physiology and Medicine, Vanderbilt University, \\ Nashville, Tennessee 37232
}

A B S TRACT The aim of the present experiments was to determine the effects of basal glucagon on glucose production after induction of prolonged insulin lack in normal conscious dogs fasted overnight. A selective deficiency of insulin or a combined deficiency of both pancreatic hormones was created by infusing somatostatin alone or in combination with an intraportal replacement infusion of glucagon. Glucose production (GP) was measured by a primed constant infusion of $\left[{ }^{3} \mathrm{H}-3\right]$ glucose, and gluconeogenesis (GNG) was assessed by determining the conversion rate of circulating $\left[{ }^{14} \mathrm{C}\right]$ alanine and $\left[{ }^{14} \mathrm{C}\right]$ lactate into $\left[{ }^{14} \mathrm{C}\right]$ glucose.

When insulin deficiency was induced in the presence of basal glucagon the latter hormone caused GP to double and then to decline so that after $4 \mathrm{~h}$ it had returned to the control rate. The conversion of alanine and lactate into glucose, on the other hand, increased throughout the period of insulin lack. Withdrawal of glucagon after GP had normalized resulted in a $40 \%$ fall in GP, a $37 \%$ decrease in GNG, and a marked decrease in the plasma glucose concentration. Induction of insulin deficiency in the absence of basal glucagon resulted in an initial (30\%) drop in GP followed by a restoration of normal GP after $2-3 \mathrm{~h}$ and moderately enhanced glucose formation from alanine and lactate.

It can be concluded that $(a)$ the effect of relative hyperglucagonemia on GP is short-lived; $(b)$ the waning of the effect of glucagon is attributable solely to a diminution of glycogenolysis because GNG remains stimulated; $(c)$ basal glucagon markedly enhances the GNG stimulation apparent after induction of insulin deficiency; and $(d)$ basal glucagon worsens the hyperglycemia pursuant on the induction of insulin de-

This work was presented in part at the Annual Meeting of the American Diabetes Association in San Francisco, Calif., June 1976.

Dr. Cherrington is a recipient of the Solomon A. Berson Award from the American Diabetes Association.

Received for publication 26 July 1977 and in revised form 21 December 1977. ficiency both by triggering an initial overproduction of glucose and by maintaining the basal production rate thereafter.

\section{INTRODUCTION}

A role for glucagon in normal physiology has recently been clearly established. The stimulatory effect of the hormone on glucose production is important for the maintenance of the glucose level both under circumstances in which its plasma concentration is basal (1-6) and under conditions in which its concentration is elevated (7-11). Recent experiments have shown that basal glucagon is of chronic importance in the maintenance of glucose production $(2,4)$ but that the effect of an increment in the glucagon concentration is shortlived, both in man $(12,13)$ and the dog $(14,15)$, even when counterregulatory insulin secretion cannot occur. It is unclear whether the effects of relative hyperglucagonemia (i.e., hyperglucagonemia produced by a deficiency of insulin rather than by glucagon excess) are also time dependent.

Similarly, the role of glucagon in diabetes mellitus is unclear (16-23). Evidence suggesting that the hormone is important has come from the finding that diabetics have basal or elevated plasma glucagon concentrations (22) and that suppression of their glucagon level is associated with a reduction of their plasma glucose concentration $(18,20)$. Contrary evidence has come from the observation that prolonged constant hyperglucagonemia of exogenous origin does not appreciably worsen the glycemic status of diabetics nor does it raise their requirement for insulin (21). It is also known that pancreatectomized man exhibits diabetic symptoms even though he lacks $3,500 \mathrm{~mol} \mathrm{wt}$ glucagon $(24,25)$.

In the above studies only changes in the plasma glucose level were measured to assess the role of glucagon in the metabolic abnormalities associated with diabetes mellitus. In none was the role of glucagon examined in terms of the mechanisms by which it regulates the 
plasma glucose concentration, namely its effects on glycogenolysis and gluconeogenesis. Such data, as well as a careful examination of the balance between the rates of glucose production and utilization, would allow a clearer understanding of the contribution of glucagon to the hyperglycemia of diabetes mellitus.

In the present studies the effects of glucagon were assessed by comparing results obtained when insulin was withdrawn in the absence and presence of a basal amount of glucagon. The specific questions addressed were $(a)$ Is the glucagon-induced overproduction of glucose which occurs as the result of selective insulin deficiency continued or short-lived? $(b)$ Is the overproduction of glucose affected by the pattern of glucagon secretion? $(c)$ Is the time course of the action of glucagon on glycogenolysis and gluconeogenesis similar? $(d)$ Is glucagon necessary for an enhancement of gluconeogenesis during insulin lack? and $(e)$ Does glucagon play a role in the maintenance of the hyperglycemia once the latter is established?

\section{METHODS}

Animals and surgical procedures. Experiments were carried out on 36 mongrel dogs $(18-25 \mathrm{~kg}$ ) of either sex, which had been fed a high protein diet (Wayne Dog Chow, Wayne Lab-Blox, Allied Mills, Inc., Chicago, Ill.) for 3-4 wk before their use. 16 days before each experiment a laparotomy was performed under general anesthesia (pentobarbital sodium, $25 \mathrm{mg} / \mathrm{kg}$ i.v.) and a silastic catheter (Dow Corning Corp., Midland, Mich.) was inserted into a tributary of the splenic vein. The tip of the catheter was advanced until it was located at the junction of the splenic and portal veins. A similar catheter was inserted into the femoral artery after a cut-down over the left inguinal area, and its tip was positioned in the left iliac artery. After their insertion both catheters were filled with saline containing heparin $(200 \mathrm{U} / \mathrm{ml}$; Abbott Laboratories, North Chicago, Ill.). Their free ends were then knotted and placed in a subcutaneous pocket so that complete closure of both skin incisions was possible.

2 wk after surgery, blood was withdrawn to determine the leukocyte count and hematocrit of the animal. Only animals which had $(a)$ a leukocyte count below $16,000 \mathrm{~mm}^{3},(b)$ a hematocrit above $38 \%$, (c) a good appetite (consuming twothirds of daily ration), and (d) normal stools were used.

On the day of an experiment, the subcutaneous ends of the catheters were freed through a small skin incision made under local anesthesia (2\% Lidocaine, Astra Pharmaceutical Products, Inc., Worcester, Mass.). The contents of each catheter was aspirated, and saline was infused through them at a slow rate $(0.1 \mathrm{ml} / \mathrm{min})$ until the experiment was begun. The splenic vein catheter was used for hormone infusion and the arterial catheter for blood sampling. Angiocaths (18 gauge; Abbott Laboratories) were inserted percutaneously into the two cephalic veins as well as the right saphenous vein. The right and left cephalic veins were used for $\left[{ }^{14} \mathrm{C}\right]$ alanine and $\left[{ }^{3} \mathrm{H}\right.$ 3]glucose infusion, respectively, whereas the saphenous vein was used for somatostatin infusion. After completion of preexperimental preparation, the conscious dog was allowed to stand calmly in a Pavlov harness for 20-30 min before the start of the experiment.

Experimental design. Most experiments consisted of an 80 -min tracer equilibration period (from -120 to $-40 \mathrm{~min}$ ) followed by a 40 -min control period (from -40 to 0 min) and a 270 or 330 -min period of hormone pertubation $(0-270$ or 330 $\min )$. The primed constant infusion of $\left[3{ }^{3} \mathrm{H}\right]$ glucose $(0.10 \mu \mathrm{Ci} /$ $\min )$ and the constant infusion of $\left[\mathrm{U}-{ }^{14} \mathrm{C}\right]$ alanine $(0.10 \mu \mathrm{Ci} / \mathrm{kg}$ per $\min$ ) were started at $t=-120$ and continued throughout the study. The priming dose of $\left[3-{ }^{3} \mathrm{H}\right]$ glucose equaled the amount of tracer infused in $140 \mathrm{~min}$.

Somatostatin (SRIF; $0.8 \mu \mathrm{g} / \mathrm{kg}$ per min) ${ }^{1}$ was infused from 0 to 270 or $330 \mathrm{~min}$ alone or in combination with intraportal glucagon and(or) insulin. Glucagon was infused either at a constant rate $(0.65 \mathrm{ng} / \mathrm{kg}$ per $\mathrm{min})$ or in a spike-decline fashion $(1.0 \mathrm{ng} / \mathrm{kg}$ per min for $30 \mathrm{~min}$ followed by $0.45 \mathrm{ng} / \mathrm{kg}$ per $\mathrm{min}$ for $60 \mathrm{~min}$ ). Insulin, when necessary, was infused at a constant rate of $300 \mu \mathrm{U} / \mathrm{kg}$ per min. Replacement of basal amounts of either pancreatic hormone was considered adequate when the resulting arterial hormone concentration did not differ by more than $20 \%$ from its control period mean value. We previously demonstrated that adequate arterial insulin and(or) glucagon replacement reflected adequate portal hormone replacement (2).

Four main types of experiments were performed: $(a)$ saline infusion, to assess the stability of the animals during the experimental period, $(b)$ somatostatin plus intraportal insulin and glucagon infusion, to examine the influence, if any, of the nonpancreatic effects of somatostatin, (c) somatostatin infusion, to determine the effect of prolonged $(4.5 \mathrm{~h})$ insulin lack during a period of glucagon deficiency, $(d)$ somatostatin plus intraportal glucagon infusion to assess the ability of basal amounts of glucagon to modify the effects of sustained $(4.5 \mathrm{~h})$ insulin deficiency. This type of experiment had three variations, one in which the glucagon was infused at a constant basal rate throughout the study, one in which the glucagon replacement was terminated part way through the study, and one in which a pulsatile pattern of glucagon infusion was used.

Blood samples were drawn every $10 \mathrm{~min}$ throughout the control period and every $15 \mathrm{~min}$ thereafter.

Processing of blood samples. The collection and immediate processing of blood samples have been described (26). The radioactivity of glucose $\left({ }^{14} \mathrm{C}\right.$ and $\left.{ }^{3} \mathrm{H}\right)$ in plasma samples was determined by previously described techniques (2) and established liquid scintillation counting procedures. Plasma glucose concentrations were determined by the glucose-oxidase method in a Beckman glucose analyzer (Beckman Instruments, Inc., Fullerton, Calif.).

Plasma $\left[{ }^{14} \mathrm{C}\right]$ alanine and $\left[{ }^{14} \mathrm{C}\right]$ lactate specific activities were determined with a short-column, ion-exchange chromatographic system which has been previously described for the analysis of alanine (26). Alanine elutes in this system with a peak retention time of $\cong 23 \mathrm{~min}$, whereas lactate elutes with a peak retention time of $4.5 \mathrm{~min}$, separate from both glucose and pyruvate. The lactate fraction of the column effluent was collected from the 4 th to the 5 th min of a run. The concentration of lactate in each fraction was measured by the method of Hohorst (27), and its radioactivity was determined by liquid scintillation counting procedures. Comparison of whole blood and plasma $\left[{ }^{14} \mathrm{C}\right]$ lactate specific activities revealed that they were identical, and because it has been previously demonstrated that plasma alanine specific activity most closely approximates the specific activity of the amino acid taken up by the splanchnic bed (26), plasma rather than whole blood, was used for analysis. The recovery of lactate was monitored in each experiment and varied from $87-95 \%$.

Immunoreactive glucagon was assayed (in plasma samples to which $500 \mathrm{U} / \mathrm{ml}$ of Trasylol had been added), with $30 \mathrm{~K}$

${ }^{1}$ Abbreviation used in this paper: SRIF, somatotropin release inhibiting factor (somatostatin). 
antiserum obtained from the University of Texas Southwestern Medical School (28). Immunoreactive insulin was measured by the Sephadex (Pharmacia Fine Chemicals, Piscataway, N. J.) bound-antibody procedure (29).

Materials. [3- $\left.{ }^{3} \mathrm{H}\right]$ glucose (New England Nuclear, Boston, Mass.) was used as the glucose tracer $(500 \mu \mathrm{Ci} / 0.005 \mathrm{mg})$ and $\left[\mathrm{U}-{ }^{14} \mathrm{C}\right]$ alanine (New England Nuclear) was used as the labeled gluconeogenic precursor $(1 \mathrm{mCi} / 0.53 \mathrm{mg})$. The contamination of $\left[{ }^{14} \mathrm{C}\right]$ alanine was determined for each batch of tracer used, and 98-99\% of the counts infused were in alanine. Insulin and glucagon were purchased from Eli Lilly and Co., Indianapolis, Ind., Phadebas Insulin Radioimmunoassay Kit was purchased from Pharmacia Fine Chemicals, Inc., and Trasylol was obtained from FBA Pharmaceuticals, Inc., New York. Glucagon 30K antiserum was obtained from Dr. Roger Unger, Dallas, Tex., and the standard glucagon and ${ }^{125}$ I-glucagon were obtained from Novo Research Institute Copenhagen, Denmark. All hormone solutions were prepared with normal saline and contained $0.3 \%$ bovine albumin. The $\left[3-{ }^{3} \mathrm{H}\right]$ glucose solution contained added glucose such that its final concentration was $1 \mathrm{mg} / \mathrm{ml}$. Cyclic somatostatin was obtained from Bachem. Inc., Marina Del Rey, Calif

Tracer methods and calculations. The rates of endogenous glucose production (rate of appearance) and utilization (rate of disappearance) were determined by the method of primed tracer infusion. Calculation of the rates was carried out according to the method of Wall et al. (30) as simplified by DeBodo et al. (31). This method is based on a single compartment analysis of glucose kinetics in which it is assumed that rapid changes in the specific activity and concentration of glucose do not occur uniformly within the entire glucose pool. To compensate for this nonuniform mixing, the nonsteady-state term of the equation was multiplied by a correction factor (pool fraction) of 0.65 as suggested previously (32). A sliding-fit technique employing three consecutive glucose and specific activity values was also used as described previously (33). Calculation of nonsteady-state turnover rates with the pool fraction method has now been validated for both inulin and glucose, and has been shown to yield accurate measurements over a wide range of deviations from steady state $(34,35)$.

Glucose clearance was calculated by dividing the rate of glucose disappearance by the plasma glucose concentration (36). This parameter responds markedly to changes in the insulin level (14) and minimally to changes in the glucose level per se (37) illustrating that it is a good index of the effects of hormones on the disposition of glucose within the body.

$\left[3-{ }^{3} \mathrm{H}\right]$ glucose was used as the tracer molecule to allow accurate assessment of the rate of glucose production $(38,39)$. Because the ${ }^{3} \mathrm{H}$ atom in position three of glucose is lost to body water and cannot recirculate $(38,40)$, its use eliminates the underestimation which might otherwise result from recycling of the label (41). The absence of recirculation in the present experiments was confirmed by the lack of either $\left[{ }^{3} \mathrm{H}\right]$ alanine or $\left[{ }^{3} \mathrm{H}\right]$ lactate in plasma after many hours of $\left[{ }^{3} \mathrm{H}\right]$ glucose infusion. The overestimate of glucose production which can arise because of loss of label as the result of futile cycling (39) is also minimal when $\left[3-{ }^{3} \mathrm{H}\right]$ glucose is used as the isotope $(38,39)$.

Gluconeogenesis was assessed with a double isotope technique recently validated and described in detail elsewhere (42). The technique involved the simultaneous infusion of two tracers, $\left[\mathrm{U}-{ }^{14} \mathrm{C}\right]$ alanine to provide labeled substrate for the gluconeogenic process and $\left[3{ }^{3} \mathrm{H}\right]$ glucose to measure glucose production. It is possible to use $\left[3-{ }^{3} \mathrm{H}\right]$ glucose to trace $\left[{ }^{14} \mathrm{C}\right]$ glucose production, just as it can be used to trace cold $\left[{ }^{12} \mathrm{C}\right]$ glucose production. The only change required in the equation of DeBodo et al. (31) is replacement of the ${ }^{\left[{ }^{12} \mathrm{C}\right] \mathrm{glu}-}$ cose concentration (milligrams per milliliter) with the $\left[{ }^{14} \mathrm{C}\right] \mathrm{glu}$ cose "concentration" (disintegrations per minute per milliliter). The production rate thus calculated has the units of disintegrations per minute per minute and represents the whole body production rate of $\left[{ }^{14} \mathrm{C}\right]$ glucose. We previously validated this method for measuring $\left[{ }^{14} \mathrm{C}\right]$ glucose production by comparing the rates which it gives with those simultaneously obtained with an arterio-venous difference technique (42). The latter is an approach used frequently $(3,26,42,43)$ in studies aimed at assessing gluconeogenesis in vivo.

Once the $\left[{ }^{14} \mathrm{C}\right]$ glucose production rate was determined, the gluconeogenic precursor conversion rate was calculated by dividing the production rate of $\left[{ }^{14} \mathrm{C}\right]$ glucose (disintegrations per minute per minute) by the gluconeogenic precursor specific activity (disintegrations per minute per micromole) as described previously $(3,26,42,43)$. It should be noted that this method does not require use of the $\left[{ }^{14} \mathrm{C}\right]$ glucose specific activity, and thus the stability of the latter parameter is not of the importance it is when the method of Kreisberg et al. (44) is used. In the present experiments, although $\left[\mathrm{U}-{ }^{14} \mathrm{C}\right]$ alanine was the infused precursor, labeled lactate

TABLE I

The Concentration, Radioactivity, and Specific Activity of Plasma Lactate during Saline Infusion in Six Postabsorptive Conscious Dogs Infused with $\left[{ }^{14} \mathrm{C}\right]$ Alanine

\begin{tabular}{|c|c|c|c|c|c|c|c|c|c|c|c|c|}
\hline & \multicolumn{3}{|c|}{ Control period } & \multicolumn{9}{|c|}{ Infusion period } \\
\hline & -40 & -20 & 0 & 30 & 60 & 90 & 120 & 150 & 180 & 210 & 240 & 270 \\
\hline SEM & 136 & 129 & 119 & 142 & 139 & $\begin{array}{l}000 \\
124\end{array}$ & 153 & $\begin{array}{l}085 \\
155\end{array}$ & $\begin{array}{l}035 \\
156\end{array}$ & $\begin{array}{l}555 \\
127\end{array}$ & $\begin{array}{l}507 \\
105\end{array}$ & $\begin{array}{r}551 \\
96\end{array}$ \\
\hline $\begin{array}{l}\text { Radioactivity, } \\
\qquad \mathrm{dpm} / \mathrm{ml}\end{array}$ & 1,428 & 1,462 & 1,533 & 1,587 & 1,674 & 1,940 & 1,963 & 1,966 & 2,176 & 1,852 & 1,858 & 1,989 \\
\hline SEM & 135 & 147 & 159 & 167 & 182 & 205 & 238 & 269 & 277 & 240 & 253 & 213 \\
\hline $\begin{array}{c}\text { Specific activity, } \\
10^{3} \mathrm{dpm} / \mathrm{mol}\end{array}$ & 2.2 & 2.3 & 2.4 & 2.3 & 2.5 & 3.0 & 2.8 & 3.0 & 3.4 & 3.3 & 3.7 & 3.6 \\
\hline SEM & 0.4 & 0.4 & 0.4 & 0.5 & 0.5 & 0.6 & 0.5 & 0.6 & 0.6 & 0.5 & 0.7 & 0.6 \\
\hline
\end{tabular}

For infusion data see Methods.

The control and infusion periods are measured in minutes. 
progressively accumulated, presumably as a result of interconversion of the two molecules and of Cori cycle activity. Because the amount of label in the plasma lactate was substantial (i.e., $1,989 \mathrm{dpm} / \mathrm{ml}$ in lactate vs. $5,210 \mathrm{dpm} / \mathrm{ml}$ in alanine at the end of the study period in control experiments; see Table I) it was not possible to use the $\left[{ }^{14} \mathrm{C}\right]$ alanine specific activity alone in the calculation of the conversion rate of substrate to glucose. Instead, a combined lactate-alanine specific activity was obtained by dividing the sum of the plasma concentrations of the two molecules by the sum of their radioactivities. The rate of conversion thus calculated represents the conversion rate of both alanine and lactate into glucose. The method canot identify whether a change is attributable to one or the other of these 3-carbon precursors, but has the advantage of being able to detect an alteration in the conversion rate regardless of which precursor is involved and regardless of whether the change occurred within the cell or at the plasma membrane (i.e., via transport).

The approach used to assess gluconeogenesis in the present study accurately measures the rate at which arterial alanine and lactate are converted into glucose. This rate, however, cannot necessarily be equated to the rate of glucose production via gluconeogenesis because a dilution of the gluconeogenic precursor specific activity usually occurs within the liver. As a result the calculated conversion rate underestimates the true gluconeogenic rate. Studies carried out to examine the effects of insulin and glucagon on the processes which dilute the gluconeogenic precursor specific activity (proteolysis and glycolysis), however, have suggested that the dilution changes minimally relative to alterations in the gluconeogenic process per se (45-47). The present method thus provides indices of gluconeogenesis, the usefulness of which lies not in their absolute values but in their relation to one another. The data were therefore plotted as percent change from base line.

Statistical comparisons were carried out by the paired and Student $t$ tests according to Snedecor and Cochran (48).

\section{RESULTS}

Effects of saline infusion on glucose turnover. Fig. 1 shows that infusion of saline did not significantly affect the plasma contentrations of insulin, glucagon, or glucose, or the mean rates of glucose production or utilization. In addition, it is evident that there was a close balance between rates of glucose movement into and out of the plasma compartment.

Effect of somatostatin plus insulin and glucagon infusion on glucose turnover. Fig. 2 shows mean data from experiments in which insulin and glucagon were replaced intraportally during somatostatin infusion. When the effect of somatostatin on the arterial insulin and glucagon concentrations was prevented SRIF failed to induce significant changes in the concentration, turnover, or clearance (Table II) of plasma glucose.

Effect of concurrent insulin and glucagon deficiency on glucose turnover. When somatostatin was administered alone for $4.5 \mathrm{~h}$ (Fig. 3), the arterial plasma glucagon level dropped by $62 \%$ to a mean value of $29 \pm 2 \mathrm{pg} / \mathrm{ml}$ and the arterial plasma insulin concentration declined by $64 \%$ to a level less than $5 \mu \mathrm{U} / \mathrm{ml}$. These hormonal changes were associated with a significant $(28 \pm 7 \%)$ but temporary fall in the rate of glucose

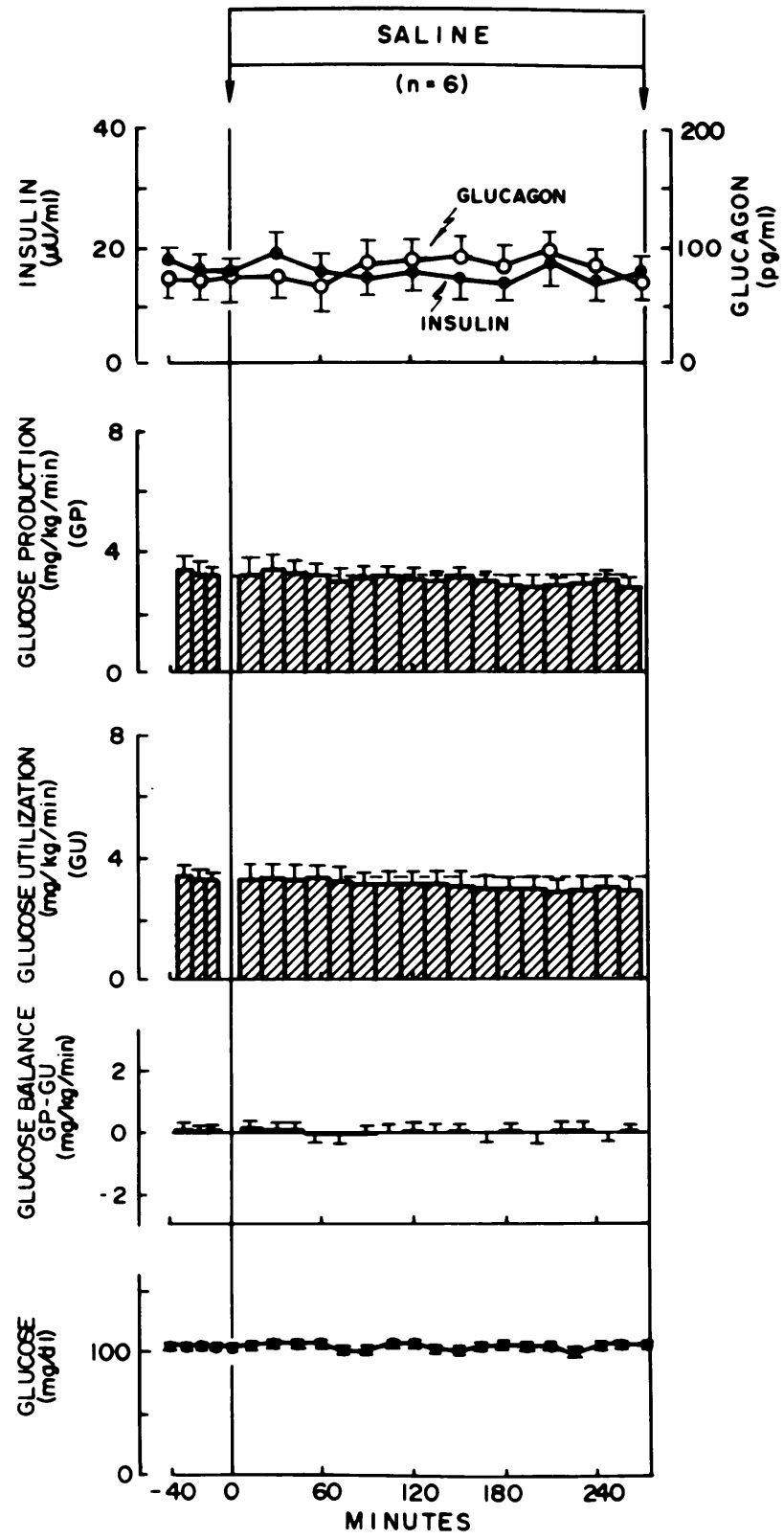

FIGURE 1 The effects of saline infusion on arterial plasma insulin and glucagon levels and on the production (GP), utilization (GU), and concentration of plasma glucose in normal conscious dogs. Values are means \pm SEM.

production. The rate of glucose utilization fell and then slowly returned to normal, presumably as a consequence of the increase in the plasma glucose level. In contrast, the clearance rate of glucose (Table II) fell progressively throughout the period of insulin lack, eventually reaching a level $36 \%$ below $(P<0.01)$ the mean control rate.

Effect of insulin deficiency induced in the presence of basal glucagon on glucose turnover. The effects of 


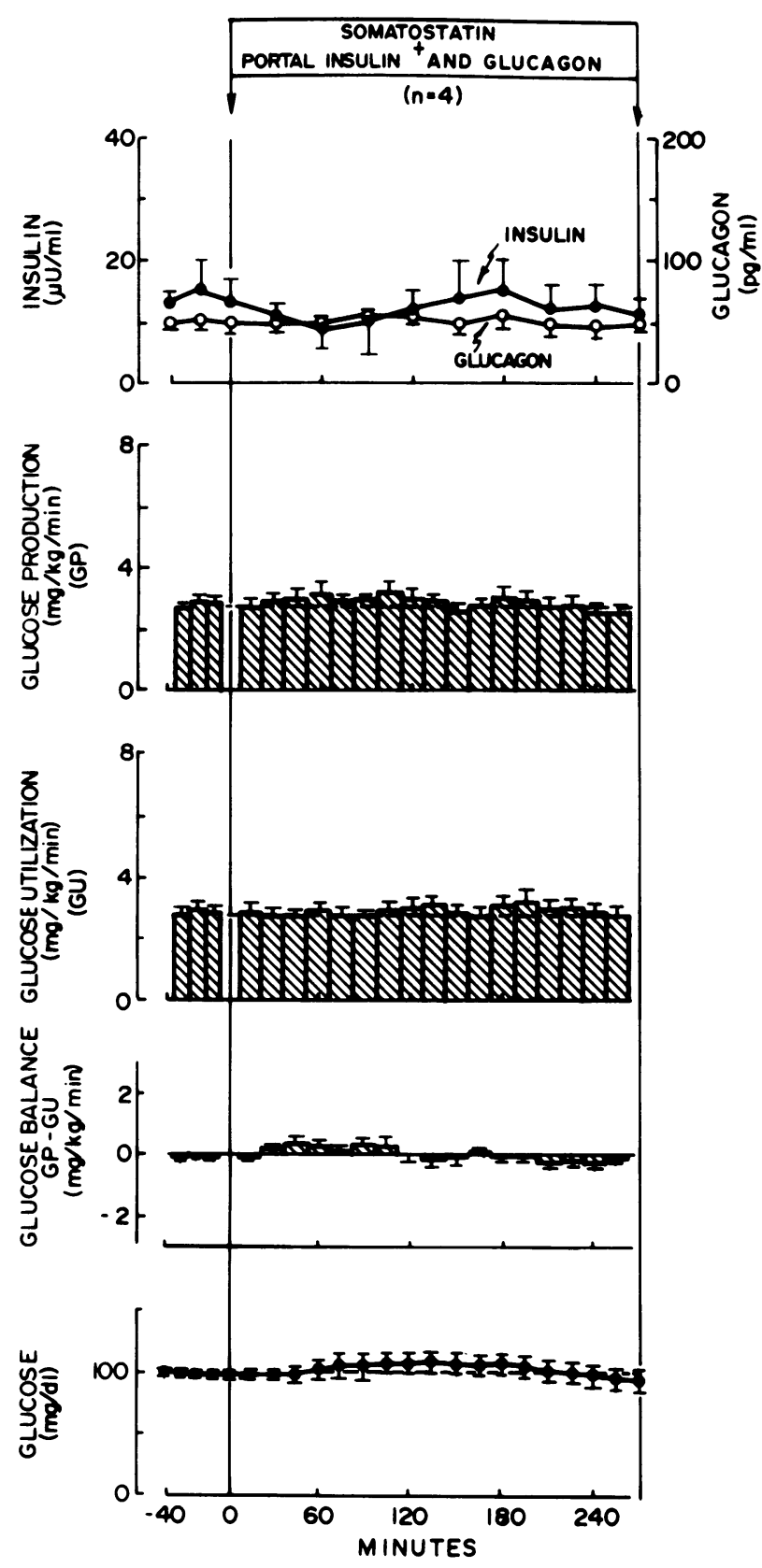

FIGURE 2 The effects of somatostatin infusion $(0.8 \mu \mathrm{g} / \mathrm{kg}$ per min) combined with intraportal replacement infusions of insulin and glucagon $(300 \mu \mathrm{U} / \mathrm{kg}$ per min and $0.65 \mathrm{ng} / \mathrm{kg}$ per min, respectively) on arterial plasma insulin and glucagon levels and on the production (GP), utilization (GU), and concentration of plasma glucose in normal conscious dogs. Values are means \pm SEM.

intraportal basal glucagon replacement on the metabolic events which occur during somatostatin administration are illustrated in Fig. 4. In these experiments the plasma glucagon level was maintained at a value $(77 \pm 8 \mathrm{pg} / \mathrm{ml})$ similar to that observed during the control period $(71 \pm 9$ $\mathrm{pg} / \mathrm{ml}$ ) and the arterial insulin level fell to less than $5 \mu \mathrm{U} / \mathrm{ml}$. Contrary to the consequences of bihormonal deficiency, selective insulin lack was associated with a marked increase in the rate of glucose production. Glucose production peaked at $30 \mathrm{~min}(84 \pm 18 \% ; P<0.01)$ and then slowly declined so that after $4 \mathrm{~h}$ it was no longer significantly elevated. Glucose utilization rose slowly despite the selective deficiency of insulin, presumably because the effect of the rising plasma glucose level offset the consequences of insulin lack.

Effect on insulin deficiency ( \pm glucagon) on the conversion of alanine and lactate into glucose. Fig. 5 shows the effects of insulin deficiency induced in the presence or absence of basal amounts of glucagon on the conversion rate of alanine and lactate into glucose. Infusion of somatostatin alone (combined insulin and glucagon deficiency) increased gluconeogenic precursor conversion into glucose by over $100 \%(P<0.01$; final mean increase of $122 \pm 18 \%$ ). Somatostatin infusion combined with glucagon replacement (selective insulin deficiency) resulted in a further twofold increase in the conversion rate of alanine and lactate into glucose (final mean increase of $289 \pm 57 \% ; P<0.01$ ). Concurrent infusion of somatostatin and replacement amounts of both pancreatic hormones resulted in a change in the conversion rate $(32 \pm 15 \%)$ that was similar to that observed in saline-infused controls $(32 \pm 8 \%$; data not shown).

Effects of insulin deficiency ( \pm glucagon) on alanine and lactate concentration. Fig. 6 shows the effects of insulin deficiency induced in the presence or absence of basal amounts of glucagon on the plasma alanine concentration. 1-2 h after the start of somatostatin administration (simultaneous insulin and glucagon deficiency) the mean arterial plasma alanine concentration began to rise, and by the end of the experiment it had doubled $(378 \pm 58$ vs. $742 \pm 148 \mu \mathrm{mol} / \mathrm{liter}$; 96\% increase; $P<0.01)$. The rise in the alanine level was associated with a significant increase in the radioactivity of the amino acid and minimal alteration in its specific activity. Replacement of glucagon substantially reduced the rise in both the radioactivity and concentration of alanine, limiting the latter to an increase of only $124 \mu \mathrm{mol} /$ liter (38\%). Concurrent replacement of both pancreatic hormones prevented any significant changes in either the radioactivity or concentration of the amino acid. The mean lactate concentration was not altered significantly by any of the hormonal perturbations.

Effects of withdrawal of glucagon after $4 h$ of insulin deficiency. Because the ability of relative hyperglucagonemia to stimulate an overproduction of glucose was short-lived, a series of experiments was undertaken to determine whether the hormone was still an important determinant of glucose production once the latter had normalized. Two additional sets of experiments, 
TABLE II

Glucose Clearance during Saline, Somatostatin, Somatostatin plus Intraportal Glucagon, and Somatostatin plus Insulin and Glucagon Infusion into Normal Conscious Dogs

\begin{tabular}{|c|c|c|c|c|c|c|c|c|c|c|c|c|c|c|c|}
\hline \multirow[b]{2}{*}{ Treatment } & \multirow[b]{2}{*}{ No. } & \multicolumn{2}{|c|}{$\begin{array}{l}\text { Control } \\
\text { period }\end{array}$} & \multicolumn{12}{|c|}{ Infusion period* ${ }^{*}$} \\
\hline & & -35 & -5 & 7.5 & 22 & & & & & 112.5 & 142.5 & 172 & & & 262.5 \\
\hline & & \multicolumn{14}{|c|}{$\mathrm{ml} / \mathrm{kg} / \mathrm{min}$} \\
\hline Saline & 6 & \multicolumn{2}{|c|}{3.03} & & 2.94 & 2.95 & 2.87 & 2.91 & 2.78 & 2.7 & & 2.74 & 2.70 & 2.70 & 2.70 \\
\hline SEM & & \multicolumn{2}{|c|}{0.31} & & .33 & 0.32 & 0.33 & 0.33 & 0.27 & 0.3 & & .24 & 0.30 & 0.25 & 0.20 \\
\hline Somatostatin & 5 & \multicolumn{2}{|c|}{3.37} & & 3.03 & 2.88 & 3.04 & 2.94 & 2.82 & 2.5 & & 2.46 & 2.33 & 2.16 & 2.18 \\
\hline SEM & & \multicolumn{2}{|c|}{0.33} & & .43 & 0.43 & 0.48 & 0.54 & 0.53 & 0.4 & & 0.44 & 0.39 & 0.31 & 0.33 \\
\hline Somatostatin plus basal & & & & & & & & & & & & & & & \\
\hline $\begin{array}{l}\text { glucagon } \\
\text { SEM }\end{array}$ & 8 & \multicolumn{2}{|c|}{3.08} & & 2.81 & 2.59 & 2.37 & 2.08 & 2.06 & 1.9 & & .80 & 1.78 & 1.75 & 1.68 \\
\hline SEM & & \multicolumn{2}{|c|}{0.11} & & 09 & 0.06 & 0.05 & 0.15 & 0.09 & 0.0 & & .07 & 0.10 & 0.10 & 0.12 \\
\hline $\begin{array}{l}\text { Somatostatin plus basal } \\
\text { glucagon plus insulin }\end{array}$ & 4 & \multicolumn{2}{|c|}{2.79} & & .88 & 2.76 & 2.74 & 2.76 & 2.70 & 2.8 & & .67 & 3.10 & 3.07 & 3.01 \\
\hline SEM & & \multicolumn{2}{|c|}{0.29} & & .35 & 0.31 & 0.33 & 0.35 & 0.27 & 0.3 & & .43 & 0.49 & 0.54 & 0.45 \\
\hline
\end{tabular}

The infusion rates of somatostatin, glucagon, and insulin were $0.8 \mu \mathrm{g} / \mathrm{kg}$ per min, $0.65 \mathrm{ng} / \mathrm{kg}$ per min, and $300 \mu \mathrm{U} / \mathrm{kg}$ per min, respectively. The three control period values were averaged to yield the control rate, whereas two consecutive values were averaged to yield each of the last seven rates during the infusion period.

* The control and infusion periods are measured in minutes.

identical to those shown in Fig. 4, were performed but continued for an additional $60 \mathrm{~min}$. In one group of animals the replacement glucagon infusion was continued to the end of the study, whereas in the other the glucagon infusion was stopped at $240 \mathrm{~min}$. In both groups the response of the plasma glucose level and glucose turnover to the first $4 \mathrm{~h}$ of selective insulin deficiency was similar to that seen previously (Fig. 4), but the responses during the subsequent $90 \mathrm{~min}$ differed and are shown in Fig. 7.

Cessation of glucagon infusion resulted in a rapid $68 \%$ fall in the plasma glucagon concentration (to $22 \pm 4 \mathrm{pg} / \mathrm{ml}$ ) and caused a marked decrease in glucose production $(40 \pm 14 \% ; P<0.01)$. The drop in glucose production caused the balance between the rates of glucose production and utilization to shift in favor of the latter thus causing a marked decrease in the plasma glucose level. Continued glucagon infusion, on the other hand, maintained the plasma glucagon level at $85 \pm 8 \mathrm{pg} / \mathrm{ml}$ and was associated with only a slight decline in glucose production ( $8 \pm 6 \%$; NS) and a negligible fall in the plasma glucose concentration.

In these experiments, as in those shown in Fig. 4, administration of somatostatin together with glucagon resulted in a marked increase in the conversion rate of alanine and lactate into glucose (Table III). Cessation of glucagon infusion and the resulting hypoglucagonemia resulted in a significant $(P<0.01)$ decrease $(37 \pm 4 \%)$ in the rate of gluconeogenic precursor conversion into glucose (Table III).

The mean arterial plasma alanine concentration in- creased minimally (from $381 \pm 24$ to $493 \pm 56 \mu \mathrm{mol} /$ liter) during SRIF + glucagon infusion (isolated insulin deficiency) but then rose markedly (to $723 \pm 71 \mu \mathrm{mol} / \mathrm{liter}$ ) once the glucagon infusion was stopped (data not shown).

Insulin deficiency with oscillating glucagon levels. A series of experiments was also undertaken to determine whether varying the pattern of intraportal glucagon infusion (but not the overall amount of the hormone delivered) would further modify the metabolic effects associated with somatostatin-induced insulin deficiency. Glucagon was infused intraportally at an above-basal rate $(1.0 \mathrm{ng} / \mathrm{kg}$ per $\mathrm{min})$ for three $30-\mathrm{min}$ periods and at a sub-basal rate $(0.45 \mathrm{ng} / \mathrm{kg}$ per $\mathrm{min})$ for intervening periods of $60 \mathrm{~min}$. The resulting immunoreactive glucagon levels (Fig. 8) reflected the infusion pattern in that the glucagon concentration increased by $44 \pm 14,52 \pm 11$, and $45 \pm 9 \mathrm{pg} / \mathrm{ml}$ during the three high infusion periods and fell to mean levels of $44 \pm 7,44 \pm 8$, and $42 \pm 5 \mathrm{pg} / \mathrm{ml}$, respectively, during the three periods of sub-basal infusion. In the virtual absence of insulin, a $40 \mathrm{pg} / \mathrm{ml}$ increment in arterial glucagon was associated with more than a doubling of the rate of glucose production. Glucose production rose by a maximum of $137 \pm 22,129 \pm 10$, and $79 \pm 5 \%$, respectively, during the three periods of hyperglucagonemia.

\section{DISCUSSION}

Transient stimulation of glucose production during relative hyperglucagonemia. A waning of the effect of 


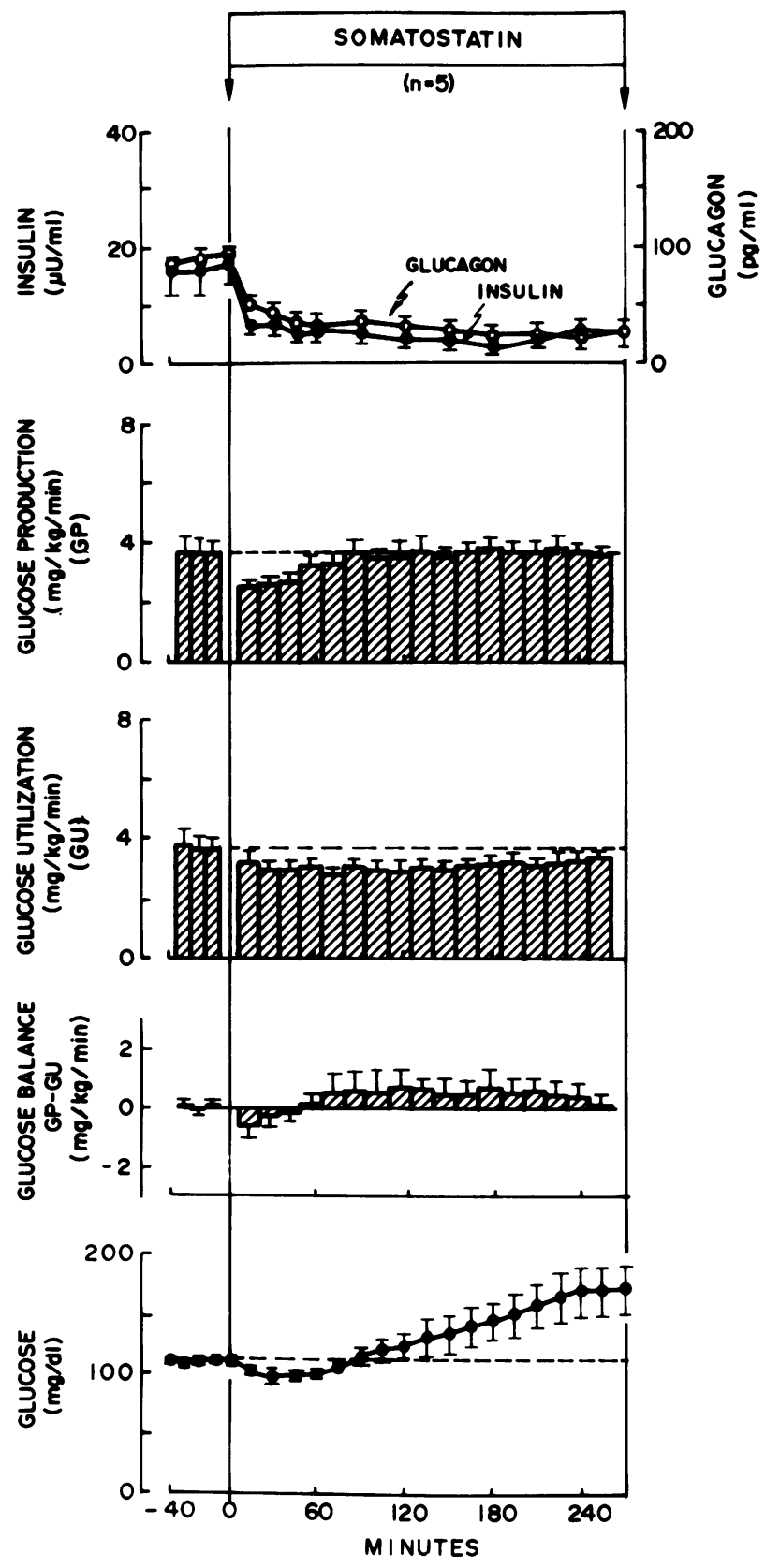

FIGURE 3 The effects of somatostatin infusion $(0.8 \mu \mathrm{g} / \mathrm{kg}$ per min) on arterial plasma insulin and glucagon levels and on the production (GP), utilization (GU), and concentration of plasma glucose in normal conscious dogs. Values are means \pm SEM.

hyperglucagonemia on glucose production has previously been demonstrated in both depancreatized and somatostatin-treated dogs maintained on constant basal insulin infusions $(14,15)$. In the present paper we show that a similar time-dependent change in glucose production occurs when relative hyperglucagonemia is pro-

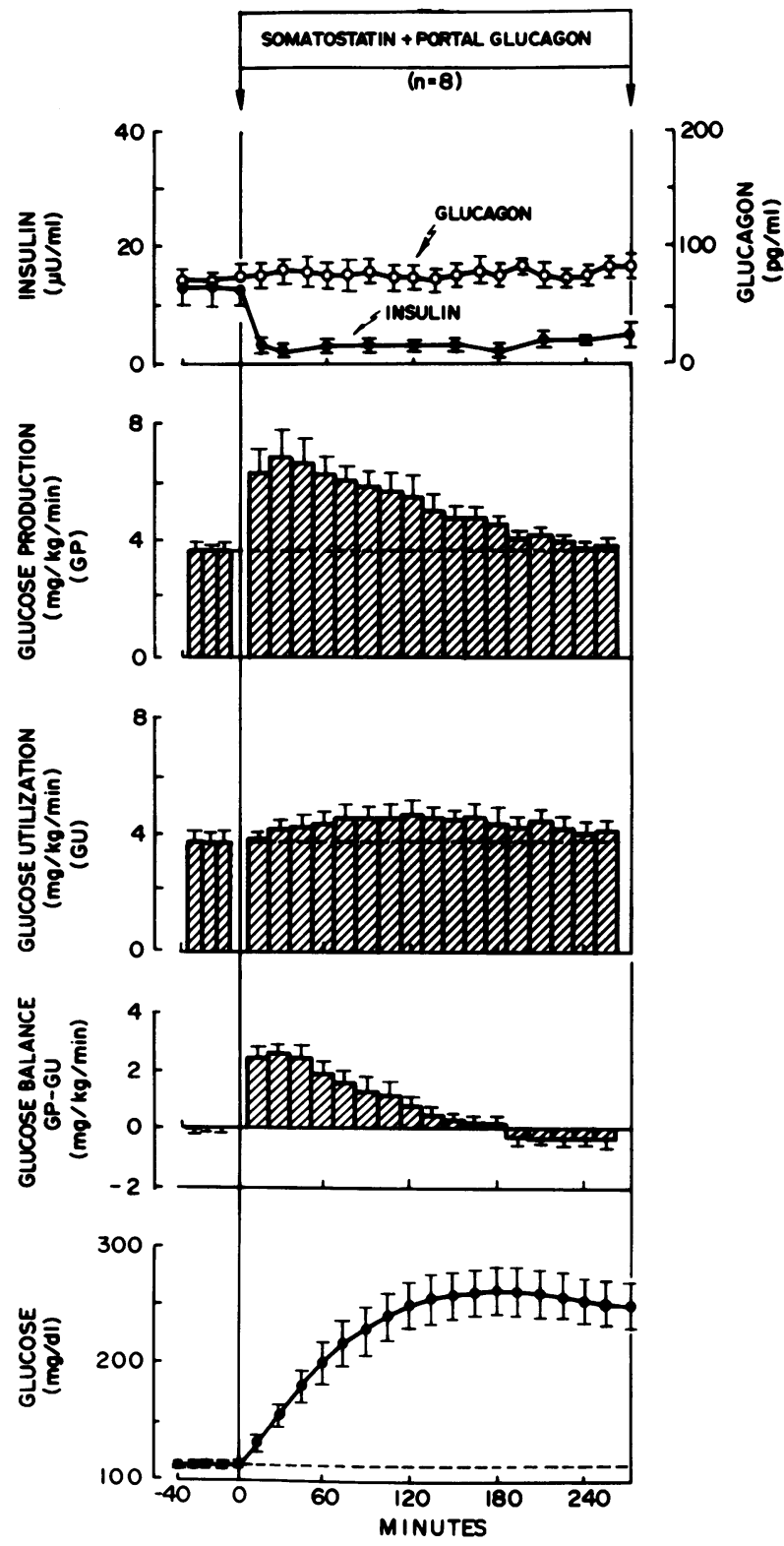

FIGURE 4 The effects of somatostatin infusion $(0.8 \mu \mathrm{g} / \mathrm{kg}$ per $\mathrm{min})$ combined with intraportal glucagon infusion $(0.65 \mathrm{ng} / \mathrm{kg}$ per min) on arterial plasma insulin and glucagon levels and on the production (GP), utilization (GU), and concentration of plasma glucose in normal conscious dogs. Values are means \pm SEM.

duced by creating insulin deficiency in the presence of basal glucagon. Sherwin et al. (49) recently noted a similar change in one human subject given a continuous infusion of somatostatin and glucagon. Although not definitive, their findings suggest that the effect of relative hyperglucagonemia may also be short-lived in man.

The decline in glucagon action in our studies was 


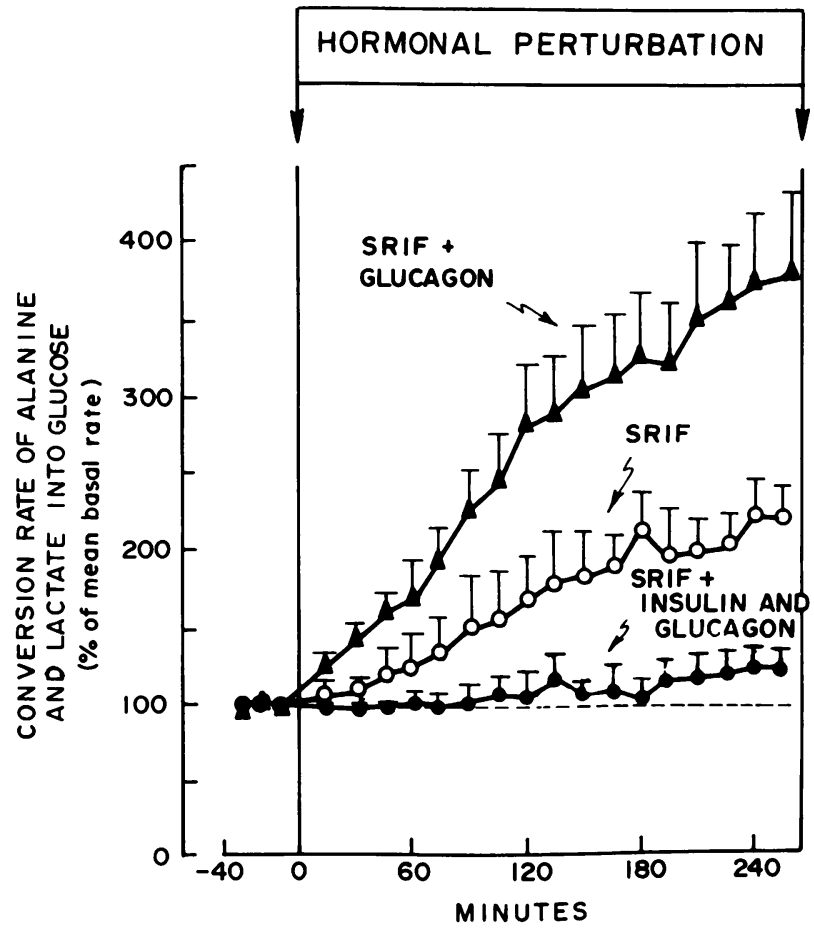

Figure 5 The effects of somatostatin $(0.8 \mu \mathrm{g} / \mathrm{kg}$ per min; $n=5)$, somatostatin $(0.8 \mu \mathrm{g} / \mathrm{kg}$ per $\mathrm{min})$ plus intraportal glucagon infusion $(0.65 \mathrm{ng} / \mathrm{kg}$ per $\min ; n=8)$, and somatostatin $(0.8 \mu \mathrm{g} / \mathrm{kg}$ per min) plus intraportal glucagon $(0.65 \mathrm{ng} / \mathrm{kg}$ per $\mathrm{min})$ and insulin $(300 \mu \mathrm{U} / \mathrm{kg}$ per min) infusion $(n=4)$ on the conversion of circulating alanine and lactate into glucose in normal conscious dogs. Results are expressed as percent change relative to the average conversion rate during the control period. Values are means \pm SEM.

probably not a result of glycogen depletion. The extra glucose produced during the 4.5 -h period of relative hyperglucagonemia was only $7.3 \mathrm{~g}$. Furthermore, when glucagon was given at a pharmacologic rate $(50 \mathrm{ng} / \mathrm{kg}$ per $\mathrm{min})$ for $1 \mathrm{~h}$ at the end of the experiment it caused the release of a further $7.5 \mathrm{~g}$ of glucose (data not shown), an amount similar to that $(9.5 \mathrm{~g})$ it released in saline-infused dogs. Although the dogs did not exhaust their liver glycogen, it remains possible that a decrease in the glycogen mass may have reduced the susceptibility of the remaining polysaccharide to degradation. In addition it is possible that the hyperglycemia associated with the breakdown of glycogen could have inhibited glucose production. Such a possibility is consistent with in vitro data $(50,51)$ but not with in vivo studies $(52,53)$ which suggest that glucose is only a weak inhibitor of hepatic glucose output unless adequate insulin is present.

Other studies have shown that the glucagon-induced splanchnic efflux of cyclic AMP in man wanes with time (54), as do the effects of the hormone on cyclic

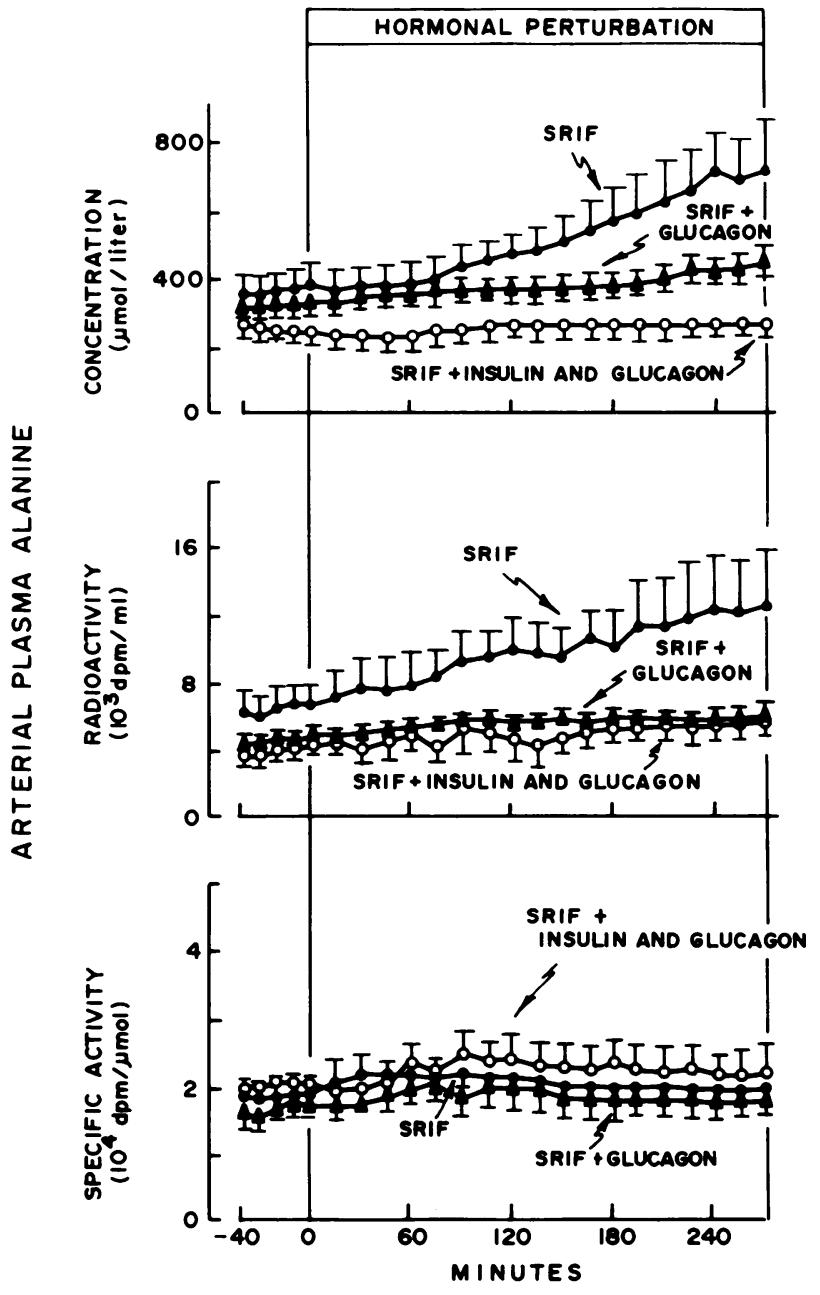

Figure 6 The effects of somatostatin $(0.8 \mu \mathrm{g} / \mathrm{kg}$ per min; $n$ $=5)$, somatostatin $(0.8 \mu \mathrm{g} / \mathrm{kg}$ per $\mathrm{min})$ plus intraportal glucagon infusion $(0.65 \mathrm{ng} / \mathrm{kg}$ per min; $n=8)$, and somatostatin $(0.8 \mu \mathrm{g} / \mathrm{kg}$ per min) plus intraportal glucagon $(0.65 \mathrm{ng} / \mathrm{kg}$ per min) and insulin $(300 \mu \mathrm{U} / \mathrm{kg}$ per min) infusion $(n=4)$ on the concentration, radioactivity, and specific activity of arterial plasma alanine in normal conscious dogs. Values are means \pm SEM.

AMP levels, cyclic AMP-dependent protein kinase activity, and phosphorylase activity in isolated rat liver cells (55). It seems likely, therefore, that more specific intracellular counterregulation may occur and that the diminution in glucose production may involve diminished activity of the glucagon receptor-adenylate cyclase complex or enhanced activity of phosphodiesterase. Because recent studies (56) suggest that glucagon receptor "down regulation" is not associated with a drop in adenylate cyclase activity, and that glucagon can stimulate hepatic cyclic AMP phosphodiesterase $(57,58)$, the involvement of the latter enzyme seems indicated.

When glucagon was infused in successive pulses, 

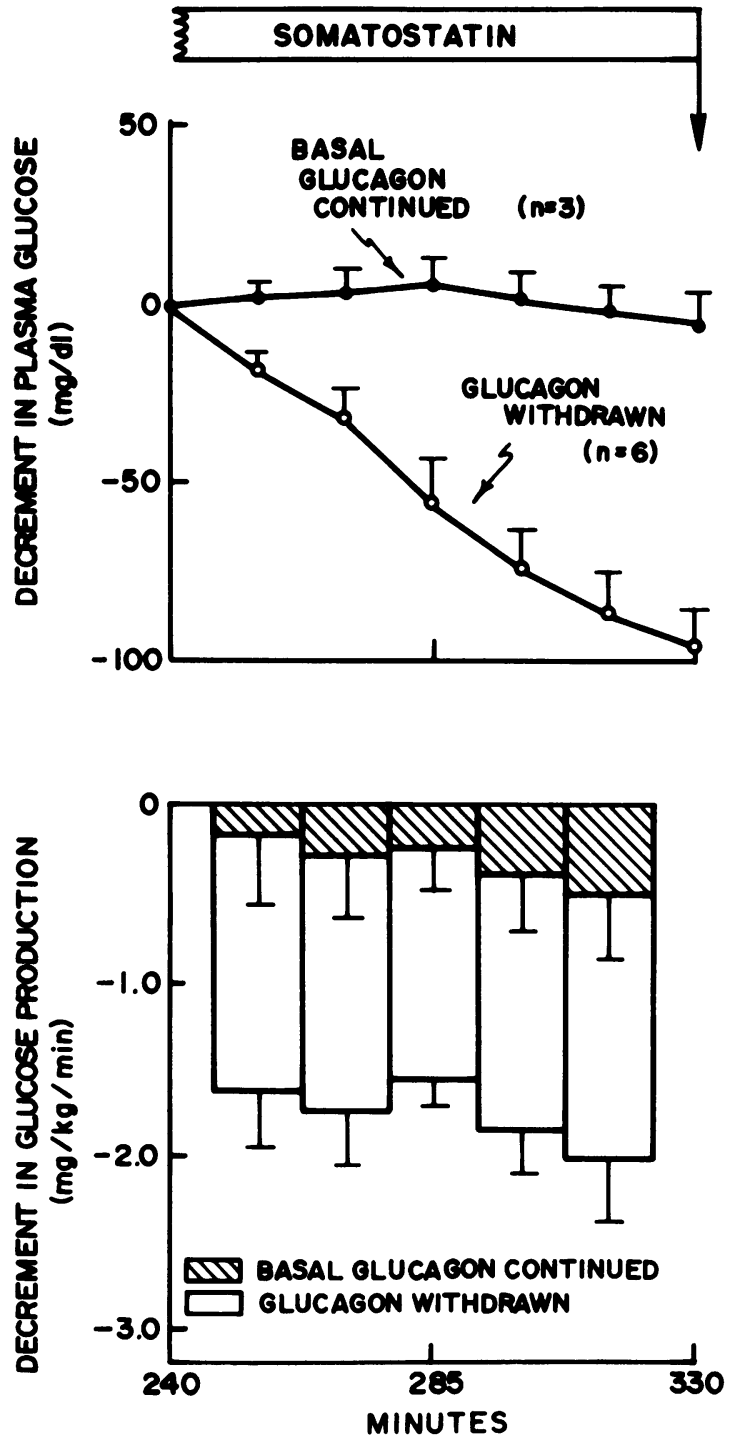

FIGURE 7 Effect of discontinuing intraportal glucagon replacement $240 \mathrm{~min}$ after the induction of insulin deficiency on the production rate and level of plasma glucose in normal conscious dogs. Data from control experiments in which the glucagon infusion $(0.65 \mathrm{ng} / \mathrm{kg}$ per $\mathrm{min})$ was not stopped are shown for comparison. The average rates of glucose production in the 30 min preceding $t=240$ were $4.28 \pm 0.26$ and $4.02 \pm 0.69 \mathrm{mg} / \mathrm{kg}$ per min in the glucagon withdrawn and control experiments, respectively. The average plasma glucose concentrations during the $30 \mathrm{~min}$ preceding $\mathrm{t}=\mathbf{2 4 0}$ were $332 \pm 11$ and $297 \pm 26 \mathrm{mg} / \mathrm{dl}$, respectively. The plasma insulin levels were similar in both groups and averaged less than $4 \mu \mathrm{U} / \mathrm{ml}$. The decrements in both parameters were significantly greater $(P<0.01)$ at all points when glucagon was withdrawn.

the amount of glucose mobilized and the resulting hyperglycemia were similar to those apparent when the hormone was infused at a constant rate. The waning effect of glucagon was still evident, this time in the form of a tachyphylaxis to successive spikes of the hormone. Thus, recovery of sensitivity to glucagon requires more time than the 90 -min interval between the hormone pulses used in this experiment.

Role of glucagon in initiating and maintaining hyperglycemia during insulin lack. Despite the falloff in the effect of glucagon on glucose production, the present studies clearly demonstrate that the hyperglycemia attributable to the hormone was not short-lived. If the glucose level had continued to decline at the rate apparent during the 4 th $\mathrm{h}$ of selective insulin lack (Fig. 4 ), it would have taken $\cong 12 \mathrm{~h}$ to reach $172 \mathrm{mg} / \mathrm{dl}$ (the maximal level achieved as the result of concurrent insulin and glucagon deficiency). Because insulin secretion was impossible, much of the sugar mobilized by glucagon was trapped in the extracellular fluid. It is thus evident that a brief burst of splanchnic glucose production, occurring as a consequence of food ingestion or hepatic glucose output, will result in prolonged hyperglycemia when insulin is deficient. It should also be noted that although mild hyperglycemia occurred when both insulin and glucagon were deficient, it was the result of decreased glucose utilization and not increased glucose production because glucose production was never significantly elevated. Such an observation confirms the vital role which basal glucagon plays in stimulating the significant overproduction of glucose which occurs in response to selective insulin deficiency.

In a recent study Sherwin et al. (49) observed a more rapid decline in the glucose level during selective insulin deficiency than we noted in our studies. This difference may be explained by the higher portal insulin:glucagon molar ratio present in the plasma of their subjects. They infused glucagon peripherally at a similar rate to that which we used portally, in all likelihood thereby underreplacing the hormone in the portal vein. In addition, they observed a moderate rise in insulin in response to somatostatin plus glucagon such that the resulting peripheral insulin concentration $(12-14 \mu \mathrm{U} / \mathrm{ml})$ was much higher than that which we observed $(<5 \mu \mathrm{U} / \mathrm{ml})$.

It is clear from the present experiments that not only was glucagon involved in the establishment of hyperglycemia but that it was also partially responsible for the maintenance of the elevated glucose concentration. When glucagon was withdrawn after $4 \mathrm{~h}$ of selective insulin lack there was a significant decrease in the rate of glucose production and a marked decline in the glucose level. The present results thus contradict the conclusion of Sherwin et al. (49) that glucagon replacement has no stimulatory effect on glucose production after prolonged insulin deficiency. These authors based their conclusion on the finding that glucose production in a patient given somatostatin + glucagon normalized after $3 \mathrm{~h}$, at which time it was 
TABLE III

Gluconeogenic Conversion of Circulating Alanine and Lactate into Glucose after the Cessation of Intraportal Glucagon Replacement $4 \mathrm{~h}$ after Induction of Insulin Deficiency Produced by Somatostatin Infusion into Normal Conscious Dogs

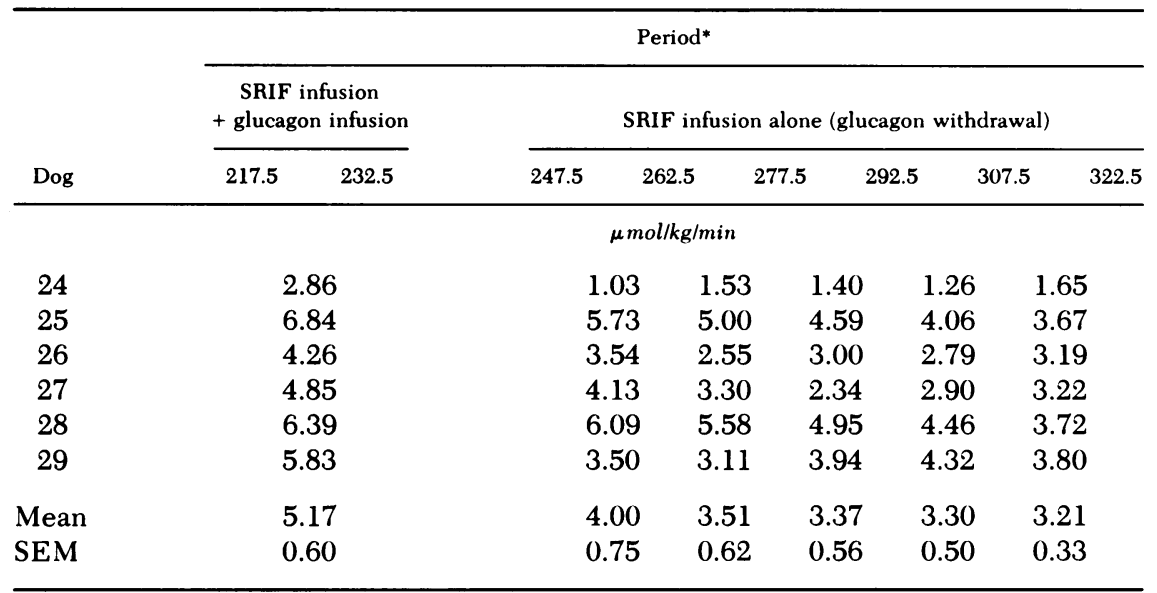

The infusion rates of somatostatin and glucagon were $0.80 \mu \mathrm{g} / \mathrm{kg}$ per min and 0.65 $\mathrm{ng} / \mathrm{kg}$ per min, respectively. The glucagon infusion was terminated after $240 \mathrm{~min}$ of selective insulin deficiency. The rate of conversion during the control period was $1.15 \pm 0.28 \mu \mathrm{mol} / \mathrm{kg}$ per min.

* The infusion periods are measured in minutes.

equivalent to the rate of glucose output apparent in the same subject given somatostatin alone. Similar observations were made in the present study (Figs. 3 and 4), but they do not warrant the conclusion that glucagon is unimportant in the ongoing stimulation of basal glucose production during insulin deficiency. Our data indicate that when glucagon is present during insulin lack it continues to be responsible for a portion of basal glucose output and thus in part for the maintenance of hyperglycemia. Although the glucose production rates were similar after $4 \mathrm{~h}$ of somatostatin infusion in the two groups described above, the plasma glucose levels were clearly different. This difference may have contributed to the similarity in the rates of glucose production since the extra plasma glucose present in the glucagon-replaced group may have exerted an inhibitory effect on glucose production which balanced the stimulatory effect of glucagon.

We have recently confirmed in man the significance of glucagon in the maintenance of hyperglycemia during insulin deficiency. Infusion of somatostatin and glucagon for $5 \mathrm{~h}$ resulted in a marked but shortlived increase in glucose production. Cessation of the glucagon infusion $5 \mathrm{~h}$ after induction of insulin deficiency caused a 53\% fall in glucose production and a decline in the plasma glucose level to $87 \mathrm{mg} / \mathrm{dl}$ over $3 \mathrm{~h}$ (59).

The conclusion that glucagon plays a role in the hyperglycemia of diabetes mellitus is also in accord with that of Raskin et al. (60), who showed that eleva- tion of the plasma glucagon level in juvenile diabetics worsened their control and markedly increased glucosuria, and Gerich (17), who showed that treatment of insulin-dependent diabetics with somatostatin improved their control and lessened both their blood sugar levels and their insulin requirements.

Effect of glucagon on the conversion of alanine and lactate into glucose during insulin lack. It is apparent from the gluconeogenic data that the time course of glucagon's effect on gluconeogenesis during the period of insulin lack was different from the time course of its action on glycogenolysis. The effect of the hormone on gluconeogenesis was either not subject to the counterregulatory changes which influenced glycogenolysis, or the time required for the effect of the hormone to wane was longer. These data imply that relative hyperglucagonemia turns the liver from an organ highly dependent on glycogenolysis to one much more dependent on gluconeogenesis for glucose production.

The gluconeogenic data also show that insulin lack significantly stimulated the conversion of circulating alanine and lactate into glucose whether glucagon was present or not. When present, however, glucagon enhanced gluconeogenesis still further. The latter conclusion is not a function of the way in which the data were expressed, because it could also be drawn when absolute conversion rates were examined. The increments in conversion observed in the three sets of experiments in which glucagon was present during 


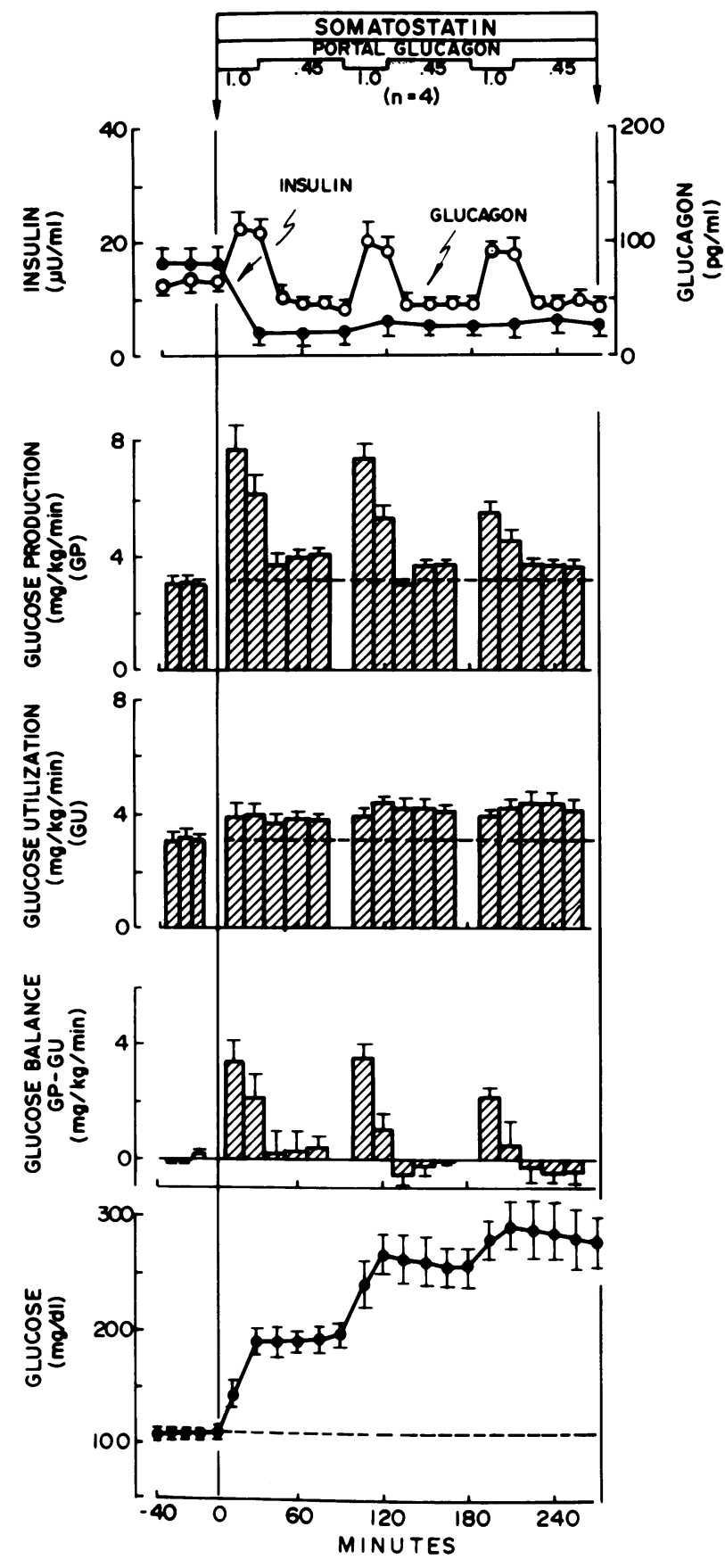

FIGURE 8 The effects of somatostatin infusion $(0.8 \mu \mathrm{g} / \mathrm{kg}$ per min) combined with a time varying glucagon infusion (see text) on arterial plasma insulin and glucagon levels and on the production, utilization, and concentration of plasma glucose in normal conscious dogs. Values are means \pm SEM.

insulin lack (i.e., those shown in Figs. 4 and 7 and Table III) were $3.43,4.02$, and $4.58 \mu \mathrm{mol} / \mathrm{kg}$ per $\mathrm{min}$ as opposed to $2.67 \mu \mathrm{mol} / \mathrm{kg}$ per $\mathrm{min}$ when insulin was made deficient in the absence of glucagon. The best evidence for the effect of basal glucagon on gluconeogenesis during insulin lack, however, can be found in the experiments in which the effects of insulin deficiency were examined in the presence and absence of glucagon (Table III). In these studies the conversion rate of alanine and lactate into glucose rose from 1.15 \pm 0.28 to $5.17 \pm 0.60 \mu \mathrm{mol} / \mathrm{kg}$ per min, when insulin lack was induced in the presence of glucagon, and then fell to $3.21 \pm 0.33 \mu \mathrm{mol} / \mathrm{kg}$ per min when glucagon was withdrawn. No gluconeogenic data were obtained in the control studies shown in Fig. 7. However, in the experiments in which the glucagon infusion was continued to $270 \mathrm{~min}$, conversion increased between 240 and $270 \mathrm{~min}$ whereas it declined markedly over the same period when the glucagon infusion was terminated.

The gluconeogenic data from the present studies are consistent with the previous finding that diabetics exhibit increased urea production (61), show an enhanced ability to convert labeled pyruvate or lactate into glucose (62), and display increased gluconeogenic precursor uptake by the splanchnic bed (63).

Effect of glucagon on the alanine concentration during insulin lack. The data from the present studies also suggest that basal insulin and glucagon play a role in the flux of alanine into and out of the plasma compartment. Selective deficiency of insulin resulted in slight but significant increase in the plasma alanine level. The increase was not associated with a detectable change in the radioactivity or specific activity of plasma alanine. Calculation of alanine turnover (using the approach described for glucose [30-34]) revealed no significant change in either the rate of plasma alanine inflow or outflow. The latter observation is not surprising when one considers then an imbalance in rates of only $2 \%$ over $4.5 \mathrm{~h}$ would have been required to cause the observed change in the alanine concentration and as such would not have been detected by our techniques.

Removal of glucagon, in addition to insulin, markedly enhanced the observed rise in the plasma alanine levels. In this case the change in level was associated with a marked rise in the radioactivity of the amino acid and little or no change in its specific activity. Calculation of alanine turnover revealed a slight $(5 \%)$ decrease in the disappearance rate of the amino acid from plasma, and although the alteration was small, it was sufficient to explain the observed rise in the alanine level. Because glucagon has previously been reported to promote alanine uptake by the liver both in vitro (64) and in vivo (63), it seems likely that glucagon withdrawal caused impaired hepatic extraction of the amino acid. A similar effect of glucagon deficiency was noted by Gerich et al. (18) who determined plasma alanine levels in insulin-dependent diabetics after insulin withdrawal in the presence or absence of glucagon. 
Effect of insulin lack \pm basal glucagon on glucose clearance. Glucose clearance decreased by $30-50 \%$ when insulin secretion was inhibited indicating that anywhere from one-third to one-half of basal glucose utilization is insulin dependent. It took at least $3 \mathrm{~h}$ for the fall in glucose clearance to be fully manifest, even though the plasma insulin concentration reached a minimum within $30 \mathrm{~min}$. A similar lag between the adjustment in the hormone level and clearance was noted when insulin infusions were terminated in depancreatized dogs (14). Because a previous study (37) showed that elevation of the blood sugar to about 230 $\mathrm{mg} / 100 \mathrm{ml}$ (in the absence of a change in the insulin or glucagon concentration) was associated with only a small drop (10\%) in clearance, it seems likely that the fall in this parameter in the present study was primarily the result of insulin deficiency and minimally attributable to the rising glucose level. The presence or absence of glucagon failed to significantly alter the effect of insulin lack on glucose clearance.

Validity of the use of somatostatin to investigate the regulation of glucose turnover. The assumptions implicit in the use of somatostatin to study carbohydrate metabolism in vivo are that the peptide has no effects on the parameters being measured other than those mediated through changes in insulin and glucagon secretion. The assumption that the nonpancreatic effects of somatostatin were without influence on the results of the present study is supported by our finding that simultaneous replacement of both insulin and glucagon during SRIF infusion prevented changes in any of the measured parameters. Such a finding is in agreement with previous data $(2,3)$, with our observation that somatostatin failed to significantly alter basal or hormone stimulated glucose output by hepatocytes (64), and with our finding that it failed to alter basal or hormone-stimulated glucose uptake by fat or muscle (65). The lack of an effect of somatostatin on the liver in vitro is consistent with some $(66,67)$ but not all other data $(68,69)$. It should be noted, however, that even when effects of somatostatin on glucose production have been observed, the concentration of the peptide required to elicit the effect was substantially greater than the levels which result from the infusion of the peptide into whole animals at rates similar to those used in the present study. In addition, examination of the hormones whose basal secretion rate is reported to be altered by somatostatin in vivo namely growth hormone, thyroid stimulating hormone, prolactin, and gastrin (70) fails to reveal a candidate likely to acutely affect glucose production.

In summary, a number of conclusions can be drawn. (a) The glucagon-stimulated overproduction of glucose, which occurs as the result of selective insulin lack (relative hyperglucagonemia), is short-lived. (b)
This drop in glucose production is a result of a decline in glycogenolysis rather than gluconeogenesis, because the conversion of alanine and lactate into glucose did not decline with time. (c) Although the production rate of glucose returns to normal $3-4 \mathrm{~h}$ after induction of insulin lack, it is still being maintained by glucagon. $(d)$ Basal glucagon thus worsens the hyperglycemia attributable to insulin lack by stimulating an initial overproduction of glucose and by maintaining basal glucose production thereafter. $(e)$ Varying the pattern (but not amount) of glucagon infusion fails to worsen the hyperglycemia attributable to the hormone. $(f)$ Although basal glucagon clearly enhances gluconeogenesis and worsens the hyperglycemia observed during a period of insulin deficiency, it is not essential for an enhancement of gluconeogenesis or for the development of hyperglycemia.

\section{ACKNOWLEDGMENTS}

The authors would like to acknowledge the excellent technical assistance of Barbara Santoro, Phillip Williams, Susan Fulcher, and Edward Fryer. We are also grateful for the excellent secretarial skills of Carolyn Sielbeck and Jan Lotterer. Lastly, we would like to express our gratitude to Doctors J. E. Liljenquist and L. S. Jefferson for their advice with regard to both the experiments and manuscript.

This investigation was supported by U. S. Public Health Service grant AM 18243, General Clinical Research Center grant 5M01 RR95, and the Vanderbilt University DiabetesEndocrinology Center grant AM 17026.

\section{REFERENCES}

1. Altszuler, N., B. Gottlieb, and J. Hampshire. 1976. Interaction of somatostatin, glucagon and insulin on hepatic glucose output in the normal dog. Diabetes. 25: 116-121.

2. Cherrington, A. D., J. L. Chiasson, J. E. Liljenquist, A. S. Jennings, U. Keller, and W. W. Lacy. 1976. The role of insulin and glucagon in the regulation of basal glucose production in the postabsorptive dog. J. Clin. Invest. 58: 1407-1418.

3. Jennings, A. S., A. D. Cherrington, J. E. Liljenquist, U. Keller, W. W. Lacy, and J. L. Chiasson. 1977. The roles of insulin and glucagon in the regulation of gluconeogenesis in the postabsorptive dog. Diabetes. 26: 847-56.

4. Keller, U., J. L. Chiasson, J. E. Liljenquist, A. D. Cherrington, A. S. Jennings, and O. B. Crofford. 1977. The roles of insulin, glucagon and free fatty acids on the regulation of ketogenesis in dogs. Diabetes. 26: 1040-51.

5. Liljenquist, J. E., G. L. Mueller, A. D. Cherrington, U. Keller, J. L. Chiasson, J. M. Perry, W. W. Lacy, and D. Rabinowitz. 1977. Evidence for an important role of glucagon in the regulation of hepatic glucose production in normal man. J. Clin. Invest. 59: 369-74.

6. Wahren, J., S. Efendic, R. Luft, L. Hagenfeldt, O. Bjorkman, and P. Felig. 1977. Influence of somatostatin on splanchnic glucose metabolism in post-absorptive and 60hour fasted humans. J. Clin. Invest. 59: 299-307.

7. Cherrington, A. D., R. Kawamori, S. Pek, and M. Vranic. 1974. Arginine infusion in dogs. Model for the roles of insulin and glucagon in regulating glucose turnover and free fatty acid levels. Diabetes. 23: 805-815. 
8. Levy, L. J., G. Spergel, and S. J. Bleicher. 1970. Glucagon deficient man: model for the role of glucagon in fasting. Program of the Proceedings of the Annual Meeting of the Endocrine Society. 1: 134.

9. Unger, R. H., and P. J. Lefebvre. 1972. Glucagon physiology. In Glucagon, Molecular Physiology, Clinical and Therapeutic Implications. P. J. Lefebvre and R. H. Unger, editors. Pergamon Press, Ltd., Oxford. 15: 213-244.

10. Unger, R. H., A. Ohneda, E. Aguilar-Parada, and A. M. Eisentraut. 1969. The role of aminogenic glucagon secretion in blood glucose homeostasis. J. Clin. Invest. 48: 810-822.

11. Vranic, M., R. Kawamori, S. Pek, N. Kovacevic, and G. A. Wrenshall. 1976. The essentiality of insulin and the role of glucagon in regulating glucose utilization and production during strenuous exercise in dogs. J. Clin. Invest. 57: 245-255.

12. Bomboy, J. E., S. B. Lewis, B. C. Sinclair-Smith, and J. E. Liljenquist. 1977. Transient stimulatory effect of sustained hyperglucagonemia on splanchnic glucose output in normal and diabetic man. Diabetes. 26: 177-184.

13. Felig, P., J. Wahren, and R. Hendler. 1976. Influence of physiologic hyperglucagonemia on basal and insulininhibited splanchnic glucose output in normal man. $J$. Clin. Invest. 58: 761-765.

14. Cherrington, A. D., and M. Vranic. 1974. Effect of interaction between insulin and glucagon on glucose turnover and FFA concentrations in normal and depancreatized dogs. Metabolism. 33: 729-744.

15. Shulman, G. I., P. E. Williams, W. W. Lacy, and A. D. Cherrington. 1977. Adaptation of glucose production to a physiological increment in glucagon. Diabetes. 26 (Suppl. 1): 383.

16. Felig, P., J. Wahren, R. Sherwin, and R. Hendler. 1976. Insulin, glucagon and somatostatin in normal physiology and diabetes mellitus. Diabetes. 25: 1091-1099.

17. Gerich, J. E. 1976. Metabolic effects of long-term somatostatin infusion in man. Metabolism. 25: 15051508.

18. Gerich, J. E., M. Lorenzi, D. M. Bier, V. Schneider, E. Tsalikian, J. H. Karam, and P. H. Forsham. 1975. Prevention of human diabetic ketoacidosis by somatostatin: evidence for an essential role for glucagon. $N$. Engl. J. Med. 292: 985-989.

19. Gerich, J. E., M. Lorenzi, J. H. Karam, V. Schneider, and P. H. Forsham. 1975. The contribution of abnormal pancreatic glucagon secretion to postprandial hyperglycemia in human diabetes mellitus. JAMA (J. Am. Med. Assoc.). 234: 159-165.

20. Sakurai, H., R. E. Dobbs, and R. H. Unger. 1975. The role of glucagon in the pathogenesis of the endogenous hyperglycemia of diabetes mellitus. Metabolism. 24: 12871298.

21. Sherwin, R. S., M. Fisher, R. Hendler, and P. Felig. 1976. Hyperglucagonemia and blood glucose regulation in normal obese and diabetic subjects. N. Engl. J. Med. 294: 455-461.

22. Unger, R. H. 1976. Diabetes and the alpha cell. Diabetes. 25: $136-151$.

23. Unger, R. H., I. Aydin, H. Nakabayashi, C. B. Srikant, and P. Raskin. 1976. The effects of glucagon administration to nondiabetics and diabetics. Metabolism. 25 (Suppl.): 1523-1526.

24. Barnes, A. J., and S. R. Bloom. 1976. Pancreatectomized man: a model for diabetes without glucagon. Lancet. I: 219-221.

25. Villanueva, M. L., J. A. Hedo, and J. Marco. 1976. Plasma glucagon immunoreactivity in a totally pancreatectomized patient. Diabetologia. 12: 613-616.

26. Chiasson, J. L., J. E. Liljenquist, B. C. Sinclair-Smith, and W. W. Lacy. 1975. Gluconeogenesis from alanine in normal postabsorptive man. Intrahepatic stimulatory effect of glucagon. Diabetes. 24: 574-584.

27. Hohorst, H. J. 1963. L-(+)Lactate determination with lactate dehydrogenase and DPN. In Methods of Enzymatic Analysis. H. U. Bergmeyer, editor. Academic Press Inc., New York 1: 266-271.

28. Aguilar-Parada, E., A. M. Eisentraut, and R. H. Unger. 1969. Pancreatic glucagon secretion in normal and diabetic subjects. Am. J. Med. Sci. 257: 415-419.

29. Wide, L., and J. Porath. 1966. Radioimmunoassay of proteins with the use of sephadex-coupled antibodies. Biochim. Biophys. Acta. 130: 257-260.

30. Wall, J. S., R. Steele, R. C. DeBodo, and N. Altszuler. 1957. Effect of insulin on utilization and production of circulating glucose. Am. J. Physiol. 189: 43-50.

31. DeBodo, R. C., R. Steele, N. Altszuler, A. Dunn, and J. S. Bishop. 1963. On the hormonal regulation of carbohydrate metabolism: studies with ${ }^{14} \mathrm{C}$-glucose. Recent Prog. Horm. Res. 19: 445-488.

32. Cowan, J. S., and G. Hetenyi, Jr. 1971. Glucoregulatory responses in normal and diabetic dogs recorded by a new tracer method. Metab. Clin. Exp. 20: 360-372.

33. Cherrington, A. D., and M. Vranic. 1973. Effect of arginine on glucose turnover and plasma free fatty acids in normal dogs. Diabetes. 22: 537-543.

34. Radziuk, J., K. H. Norwich, and M. Vranic. 1974. Measurement and validation of nonsteady turnover rates with applications to the inulin and glucose system. Fed. Proc. 33: $1855-1864$.

35. Radziuk, J., M. Vranic, and K. H. Norwich. 1978. Experimental validation of measurements of glucose turnover in nonsteady state. Am. J. Physiol. 234: E84-E95.

36. Riggs, D. S. 1963. The Mathematical Approach to Physiological Problems. The Williams \& Wilkins Co., Baltimore, Md.

37. Cherrington, A. D., P. E. Williams, and M. S. Harris. 1978. The relationship between the plasma glucose level and glucose uptake in the conscious dog. Metabolism. In press.

38. Altszuler, N., A. Barkai, C. Bjerknes, B. Gottlieb, and R. Steele. 1975. Glucose turnover values in the dog obtained with various species of labeled glucose. Am. J. Physiol. 229: 1662-1667.

39. Dunn, A., K. Bever, M. Chenoweth, and J. Katz. 1976. Estimation of glucose turnover and recycling in rabbits using various ${ }^{3} \mathrm{H}$ and ${ }^{14} \mathrm{C}$ glucose labels. Am. J. Physiol. 230: $1159-1162$.

40. Katz, J., and A. Dunn. 1967. Glucose-2-T as a tracer for glucose metabolism. Biochemistry. 6: 1-5.

41. Cherrington, A. D., M. Vranic, P. Fono, and N. Kovacevic. 1972. Effect of glucagon on glucose turnover and plasma free fatty acids in depancreatized dogs maintained on matched insulin infusions. Can. J. Physiol. Pharmacol. 50: 946-954.

42. Chiasson, J. L., J. E. Liljenquist, A. S. Jennings, W. W. Lacy, and A. D. Cherrington. 1977. Gluconeogenesis: methodological approaches in vivo. Fed. Proc. 36: 230235.

43. Hall, S. E. H., R. Goebel, I. Barnes, G. Hetenyi, and M. Berman. 1977. The turnover and conversion to glucose of alanine in newborn and grown dogs. Fed. Proc. 36: 239-244.

44. Kreisberg, R. A., L. F. Pennington, and B. R. Boshell. 1970. 
Lactate turnover and gluconeogenesis in normal obese humans: effect of starvation. Diabetes. 19: 53-63.

45. Ayuso-Parilla, M. S., A. Martin-Requero, J. Perez-Dier, and R. Parilla. 1976. Role of glucagon on control of hepatic protein synthesis and degradation in the rat in vivo. J. Biol. Chem. 251: 7785-7793.

46. Mortimore, G. E., and C. E. Mondon. 1970. Inhibition by insulin of valine turnover in liver. J. Biol. Chem. 245: 2375-2382.

47. Exton, J. H., and C. R. Park. 1967. Control of gluconeogenesis in liver. J. Biol. Chem. 242: 2622-2631.

48. Snedecor, G. W., and W. G. Cochran. 1967. Statistical Methods. Iowa State University Press, Ames, Iowa. 6th edition. 593.

49. Sherwin, R. S., W. Tamborlane, R. Hendler, L. Sacca, R. A. DeFronzo, and P. Felig. 1977. Influence of glucagon replacement on the hyperglycemic and hyperketonemic response to prolonged somatostatin infusion in normal man. J. Clin. Endocrinol. Metab. 45: 1104-1107.

50. Bucolo, R. J., R. N. Bergman, D. J. Marsh, and F. E. Yates. 1974. Dynamics of the isolated blood-perfused canine liver. Am. J. Physiol. 227: 209-217.

51. Glinsmann, W. H., E. P. Hern, and A. Lynch. 1969. Intrinsic regulation of glucose output by rat liver. Am.J. Physiol. 216: 698-703.

52. Ishiwata, K., G. Hetenyi, Jr., and M. Vranic. 1969. Effect of d-glucose or d-ribose on the turnover of glucose in pancreatectomized dogs maintained on a matched intraportal infusion of insulin. Diabetes. 12: 820-827.

53. Wahren, J., P. Felig, E. Cerasi, and R. Luft. 1972. Splanchnic and peripheral glucose and amino acid metabolism in diabetes mellitus. J. Clin. Invest. 51: 1870-1878.

54. Liljenquist, J. E., J. D. Bomboy, S. B. Lewis, B. C. Sinclair-Smith, P. W. Felts, W. W. Lacy, O. B. Crofford, and G. W. Liddle. 1974. Effects of glucagon on lipolysis and ketogenesis in normal and diabetic man. J. Clin. Invest. 52: 190-197.

55. Cherrington, A. D., and J. H. Exton. 1976. Studies on the role of cyclic AMP dependent protein kinase in the actions of glucagon and catecholamines on liver glycogen metabolism. Metabolism. 25(Suppl. 1): 1351-1354.

56. Freeman, D., K. McCorkle, and C. B. Srikant. 1977. Effect of hyperglucagonemia on glucagon binding and biologic activity. Diabetes. 26(Suppl. 1): 366.

57. Loten, E. G., F. D. Assimacopoulos-Jeannet, J. H. Exton, and C. R. Park. 1978. Stimulation of a low KM phosphodiesterase from liver by insulin and glucagon. J. Biol. Chem. In press.
58. Allan, E. H., and J. G. T. Sneyd. 1975. An effect of glucagon on $3^{\prime}, 5^{\prime}$-cyclic AMP in isolated rat hepatocytes. Biochem. Biophys. Res. Commun. 62: 594-601.

59. Bloomgarden, Z. T., J. E. Liljenquist, and D. Rabinowitz. 1978. Persistent stimulatory effect of glucagon on hepatic glucose production despite "down-regulation." Clin. Res. 26: 195.

60. Raskin, P., and R. H. Unger. 1977. Effects of exogenous hyperglucagonemia in insulin-treated diabetics. Diabetes. 26: 1034-1039.

61. Bondy, P. K., W. L. Bloom, and V. S. Whitner. 1949. Studies on the role of the liver in human carbohydrate metabolism by the venous catheter technique II. Patients with diabetic ketosis before and after the administration of insulin. J. Clin. Invest. 28: 1126-1133.

62. DeMeutter, R. C., and W. W. Shreeve. 1963. Conversion of DL-lactate-2-C or 3-C or pyruvate-2-C to blood glucose in humans: effects of diabetes, insulin tolbutamide and glucose load. J. Clin. Invest. 42: 525-532.

63. Felig, P. 1973. The glucose-alanine cycle. Metabolism. 24: 179-207.

64. Mallette, L. E., J. H. Exton, and C. R. Park. 1969. Effects of glucagon on amino acid transport and utilization in the perfused rat liver. J. Biol. Chem. 224: 5724-5728.

65. Cherrington, A. D., M. D. Caldwell, M. R. Dietz, J. H. Exton, and O. B. Crofford. 1977. The effect of somatostatin on glucose uptake and production by rat tissues in vitro. Diabetes. 26: 740-748.

66. Chideckel, E., J. Palmer, D. H. Keorker, J. Ensinck, M. B. Davidson, and C. J. Goodner. 1975. Somatostatin blockade of acute and chronic stimuli of the endocrine pancreas and consequences of this blockade on glucose homeostasis. J. Clin. Invest. 55: 754-762.

67. Gerich, J. E., D. Bier, R. Haas, C. Wood, R. Byrne, and J. C. Penhos. 1975. In vitro and in vivo effects of somatostatin on glucose, alanine and ketone metabolism in the rat. Endocrinology. 96: A128.

68. Oliver, J. R., and S. R. Wagle. 1975. Studies on the inhibition of insulin release, glycogenolysis and gluconeogenesis by somatostatin in rat islets of transplants and isolated hepatocytes. Biochem. Biophys. Res. Commun. 62: 722-777.

69. Sacks, H., K. Waligora, J. Matthews, and B. Pimstone. 1977. Inhibition by somatostatin of glucagon-induced glucose release from the isolated perfused rat liver. Endocrinology. 101: 1751-1759.

70. Guillemin, R., and J. E. Gerich. 1976. Somatostatin: physiological and clinical significance. Annu. Rev. of Med. 27: 379-389. 